\title{
Progress in green energies sustainable development and the environment
}

\begin{abstract}
Globally, buildings are responsible for approximately $40 \%$ of the total world annual energy consumption. Most of this energy is for the provision of lighting, heating, cooling, and air conditioning. Increasing awareness of the environmental impact of $\mathrm{CO}_{2}, \mathrm{NO}_{x}$ and $\mathrm{CFCs}$ emissions triggered a renewed interest in environmentally friendly cooling, and heating technologies. Under the 1997 Montreal Protocol, governments agreed to phase out chemicals used as refrigerants that have the potential to destroy stratospheric ozone. It was therefore considered desirable to reduce energy consumption and decrease the rate of depletion of world energy reserves and pollution of the environment. This article discusses a comprehensive review of energy sources, environment and sustainable development. This includes all the renewable energy technologies, energy efficiency systems, energy conservation scenarios, energy savings and other mitigation measures necessary to reduce climate change.
\end{abstract}

Keywords: sustainable development, mitigation measurements, energy savings, mitigation, energy conservation, energy efficiency, scenarios, environment, earth, living tissue, sunlight
Volume I Issue 3 - 2017

\author{
Abdeen Mustafa Omer \\ Energy Research Institute, UK
}

Correspondence: Abdeen Mustafa Omer, Energy Research Institute, United Kingdom, Tel 0044 | I59 787। 7 ,

Email abdeenomer2@yahoo.co.uk

Received: August 17, 2017 | Published: October 06, 2017
Abbreviations: GHG, global temperature and greenhouse gas; WS, world summit; RETs, renewable energy technologies; TPPs, thermal power projects

\section{Introduction}

Over millions of years ago plants covered the earth, converting the energy of sunlight into living tissue, some of which was buried in the depths of the earth to produce deposits of coal, oil and natural gas. During the past few decades has found many valuable uses for these complex chemical substances, manufacturing from them plastics, textiles, fertilisers and the various end products of the petrochemical industry. Each decade sees increasing uses for these products. Coal, oil and gas are non-renewable natural resources, which will certainly be of great value to future generations, as they are to ours. The rapid depletion of non-renewable fossil resources need not continue, since it is now or soon will be technically and economically feasible to supply all of man's need from the most abundant energy source of all, the sun. The sunlight is not only inexhaustible; it is the only energy source, which is completely non-polluting. ${ }^{1}$ Industry's use of fossil fuels has been blamed for our warming climate. When coal, gas and oil are burnt, they release harmful gases, which trap heat in the atmosphere and cause global warming. However, there has been an ongoing debate on this subject, as scientists have struggled to distinguish between changes, which are human induced, and those, which could be put down to natural climate variability.

Industrialised countries have the highest emission levels, and must shoulder the greatest responsibility for global warming. However, action must also be taken by developing countries to avoid future increases in emission levels as their economies develop and population grows. Human activities that emit carbon dioxide $\left(\mathrm{CO}_{2}\right)$, the most significant contributor to potential climate change, occur primarily from fossil fuel production. Consequently, efforts to control $\mathrm{CO}_{2}$ emissions could have serious, negative consequences for economic growth, employment, investment, trade and the standard of living of individuals everywhere. Scientifically, it is difficult to predict the relationship between global temperature and greenhouse gas (GHG) concentrations. The climate system contains many processes that will change if warming occurs. Critical processes include heat transfer by winds and currents, the hydrological cycle involving evaporation, precipitation, runoff and groundwater and the formation of clouds, snow, and ice, all of which display enormous natural variability. The equipment and infrastructure for energy supply and use are designed with long lifetimes, and the premature turnover of capital stock involves significant costs.

Economic benefits occur if capital stock is replaced with more efficient equipment in step with its normal replacement cycle. Likewise, if opportunities to reduce future emissions are taken in a timely manner, they should be less costly. Such flexible approaches would allow society to take account of evolving scientific and technological knowledge, and to gain experience in designing policies to address climate change. ${ }^{2}$ The World Summit (WS) on Sustainable Development in Johannesburg committed itself to "encourage and promote the development of renewable energy sources to accelerate the shift towards sustainable consumption and production". The WS aimed at breaking the link between resource use and productivity. It is about:

a. Trying to ensure economic growth doesn't cause environmental pollution.

b. Improving resource efficiency.

c. Examining the whole life-cycle of a product.

d. Enabling consumers to receive more information on products and services.

e. Examining how taxes, voluntary agreements, subsidies, regulation and information campaigns, can best stimulate innovation and investment to provide cleaner technology.

Examining how taxes, voluntary agreements, subsidies, regulation and information campaigns, can best stimulate innovation and 
investment to provide cleaner technology. The energy conservation scenarios include rational use of energy policies in all economy sectors and use of combined heat and power systems, which are able to add to energy savings from the autonomous power plants. Electricity from renewable energy sources is by definition the environmental green product. Hence, a renewable energy certificate system is an essential basis for all policy systems, independent of the renewable energy support scheme. It is, therefore, important that all parties involved support the renewable energy certificate system in place. Existing renewable energy technologies (RETs) could play a significant mitigating role, but the economic and political climate will have to change first. Climate change is real. It is happening now, and GHGs produced by human activities are significantly contributing to it. The predicted global temperature increase of between 1.5 and $4.5^{\circ} \mathrm{C}$ could lead to potentially catastrophic environmental impacts. These include sea level rise, increased frequency of extreme weather events, floods, droughts, disease migration from various places and possible stalling of the Gulf Stream. This has led scientists to argue that climate change issues are not ones that politicians can afford to ignore, and policy makers tend to agree. ${ }^{3}$ However, reaching international agreements on climate change policies is no trivial task.

Renewable energy is the term used to describe a wide range of naturally occurring, replenishing energy sources. The use of renewable energy sources and the rational use of energy are the fundamental inputs for any responsible energy policy. The energy sector is encountering difficulties because increased production and consumption levels entail higher levels of pollution and eventually climate change, with possibly disastrous consequences. Moreover, it is important to secure energy at an acceptable cost in order to avoid negative impacts on economic growth. On the technological side, renewables have an obvious role to play. In general, there is no problem in terms of the technical potential of renewables to deliver energy. Moreover, there are very good opportunities for RETs to play an important role in reducing emissions of GHGs into the atmosphere, certainly far more than have been exploited so far. However, there are still some technical issues to address in order to cope with the intermittency of some renewables, particularly wind and solar. Yet, the biggest problem with relying on renewables to deliver the necessary cuts in GHG emissions is more to do with politics and policy issues than with technical ones. ${ }^{3}$

The single most important step governments could take to promote and increase the use of renewables is to improve access for renewables to the energy market. This access to the market would need to be under favourable conditions and, possibly, under favourable economic rates as well. One move that could help, or at least justify, better market access would be to acknowledge that there are environmental costs associated with other energy supply options and that these costs are not currently internalised within the market price of electricity or fuels. This could make a significant difference, particularly if appropriate subsidies were applied to renewable energy in recognition of the environmental benefits it offers. Similarly, cutting energy consumption through end-use efficiency is absolutely essential. This suggests that issues of end-use consumption of energy will have to come into the discussion in the foreseeable future.

\section{Energy and population growth}

Throughout the world urban areas have increased in size during recent decades. About $50 \%$ of the world's population and approximately $7.6 \%$ in more developed countries are urban dwellers. Even though there is evidence to suggest that in many 'advanced' industrialised countries there has been a reversal in the rural-to-urban shift of populations, virtually all population growth expected between 2000 and 2030 will be concentrated in urban areas of the world. With an expected annual growth of $1.8 \%$, the world's urban population will double in 38years. ${ }^{1}$ With increasing urbanisation in the world, cities are growing in number, population and complexity. At present, $2 \%$ of the world's land surface is covered by cities, yet the people living in them consume $75 \%$ of the resources consumed by mankind. ${ }^{2}$ Indeed, the ecological footprint of cities is many times larger than the areas they physically occupy. Economic and social imperatives often dictate that cities must become more concentrated, making it necessary to increase the density to accommodate the people, to reduce the cost of public services, and to achieve required social cohesiveness. The reality of modern urbanization inevitably leads to higher densities than in traditional settlements and this trend is particularly notable in developing countries.

The world population is rising rapidly, notably in the developing countries. Historical trends suggest that increased annual energy use per capita is a good surrogate for the standard of living factors, which promote a decrease in population growth rate. If these trends continue, the stabilisation of the world's population will require the increased use of all sources of energy, particularly as cheap oil and gas are depleted. The improved efficiency of energy use and renewable energy sources will, therefore, is essential in stabilizing population, while providing a decent standard of living all over the world. ${ }^{3}$ Moreover, energy is the vital input for economic and social development of any country. With an increase in industrial and agricultural activities the demand for energy is also rising. It is a well-accepted fact that commercial energy use has to be minimised. This is because of the environmental effects and the availability problems. The focus has now shifted to noncommercial energy resources, which are renewable in nature. This is found to have less environmental effects and also the availability is guaranteed.

Even though the ideal situation will be to enthuse people to use renewable energy resources, there are many practical difficulties, which need to be tackled. The people groups who are using the non-commercial energy resources, like urban communities, are now becoming more demanding and wish to have commercial energy resources made available for their use. This is attributed to the increased awareness, improved literacy level and changing culture. ${ }^{3}$ The quality of life practiced by people is usually represented as being proportional to the per capita energy use of that particular country. It is not surprising that people want to improve their quality of life. Consequently, it is expected that the demand for commercial energy resources will increase at a greater rate in the years to come. ${ }^{3}$ Because of this emerging situation, the policy makers are left with two options: either concentrate on renewable energy resources and have them as substitutes for commercial energy resources or have a dual approach in which renewable energy resources will contribute to meet a significant portion of the demand whereas the conventional commercial energy resources would be used with caution whenever necessary. Even though the first option is the ideal one, the second approach will be more appropriate for a smooth transition. ${ }^{3}$ Worldwide, renewable energy contributes as much as $20 \%$ of the global energy supplies. ${ }^{4}$ Over two thirds of this comes from biomass use, mostly in developing countries, some of it unsustainable. Yet, the potential for energy from sustainable technologies is huge.

The RETs have the benefit of being environmentally benign when developed in a sensitive and appropriate way with the full involvement of local communities. In addition, they are diverse, 
secure, locally based and abundant. In spite of the enormous potential and the multiple benefits, the contribution from renewable energy still lags behind the ambitious claims for it due to the initially high development costs, concerns about local impacts, lack of research funding and poor institutional and economic arrangements. ${ }^{4}$ An approach is needed to integrate renewable energies in a way to meet high building performance. However, because renewable energy sources are stochastic and geographically diffuse, their ability to match demand is determined by adoption of one of the following two approaches: ${ }^{5}$ the utilisation of a capture area greater than that occupied by the community to be supplied, or the reduction of the community's energy demands to a level commensurate with the locally available renewable resources.

\section{Energy saving in buildings}

The prospects for development in power engineering are, at present, closely related to ecological problems. Power engineering has harmful effects on the environment, as it discharges toxic gases into atmosphere and also oil-contaminated and saline waters into rivers, while polluting the soil with ash and slag and having adverse effects on living things on account of electromagnetic fields and so on. There is thus an urgent need for new approaches to provide an ecologically safe strategy. Substantial economic and ecological effects for thermal power projects (TPPs) can be achieved by improvement, upgrading the efficiency of the existing equipment, reduction of electricity loss, saving of fuel, and optimisation of its operating conditions and service life. Improving access for rural and urban low-income areas in developing countries through energy efficiency and renewable energies is important. Sustainable energy is a prerequisite for development. Energy-based living standards in developing countries, however, are clearly below standards in developed countries. Low levels of access to affordable and environmentally sound energy in both rural and urban low-income areas are therefore a predominant issue in developing countries.

In recent years many programmes for development aid or technical assistance have been focusing on improving access to sustainable energy, many of them with impressive results. Apart from success stories, however, experience also shows that positive appraisals of many projects evaporate after completion and vanishing of the implementation expert team. Altogether, the diffusion of sustainable technologies such as energy efficiency and renewable energies for cooking, heating, lighting, electrical appliances and building insulation in developing countries has been slow. Energy efficiency and renewable energy programmes could be more sustainable and pilot studies more effective and pulse releasing if the entire policy and implementation process was considered and redesigned from the outset. New financing and implementation processes are needed which allow reallocating financial resources and thus enabling countries themselves to achieve a sustainable energy infrastructure. The links between the energy policy framework, financing and implementation of renewable energy and energy efficiency projects have to be strengthened and capacity building efforts are required.

The admission of daylight into buildings alone does not guarantee that the design will be energy efficient in terms of lighting. In fact, the design for increased daylight can often raise concerns relating to visual comfort (glare) and thermal comfort (increased solar gain in the summer and heat losses in the winter from larger apertures). Such issues will clearly need to be addressed in the design of the window openings, blinds, shading devices, heating system, etc. In order for a building to benefit from daylight energy terms, it is a prerequisite that lights are switched off when sufficient daylight is available. The nature of the switching regime; manual or automated, centralized or local, switched, stepped or dimmed, will determine the energy performance. Simple techniques can be implemented to increase the probability that lights are switched off. ${ }^{6}$

These include:

i. Making switches conspicuous.

ii. Loading switches appropriately in relation to the lights.

iii. Switching banks of lights independently.

iv. Switching banks of lights parallel to the main window wall.

v. There are also a number of methods, which help reduce the lighting energy use, which, in turn, relate to the type of occupancy pattern of the building. ${ }^{6}$

\section{The light switching options include:}

a. Centralized timed off (or stepped)/manual on.

b. Photoelectric off (or stepped)/manual on.

c. Photoelectric and on (or stepped), photoelectric dimming

d. Occupant sensor (stepped) on/off (movement or noise sensor).

Likewise, energy savings from the avoidance of air conditioning can be very substantial. Whilst day-lighting strategies need to be integrated with artificial lighting systems in order to become beneficial in terms of energy use, reductions in overall energy consumption levels by employment of a sustained programme of energy consumption strategies and measures would have considerable benefits within the buildings sector. The perception is often given however is that rigorous energy conservation as an end in itself imposes a style on building design resulting in a restricted aesthetic solution. It would perhaps be better to support a climate sensitive design approach, which encompassed some elements of the pure conservation strategy together with strategies, which work with the local ambient conditions making use of energy technology systems, such as solar energy, where feasible. In practice, low energy environments are achieved through a combination of measures that include:

a. The application of environmental regulations and policy.

b. The application of environmental science and best practice.

c. Mathematical modeling and simulation.

d. Environmental design and engineering.

e. Construction and commissioning.

f. Management and modifications of environments in use.

While the overriding intention of passive solar energy design is to achieve a reduction in purchased energy consumption, the attainment of significant savings is in doubt. The non-realisation of potential energy benefits is mainly due to the neglect of the consideration of post-occupancy user and management behaviour by energy scientists and designers alike. Buildings consume energy mainly for cooling, heating and lighting. The energy consumption was based on the assumption that the building operates within ASHRAE-thermal comfort zone during the cooling and heating periods. ${ }^{7}$ Most of the buildings incorporate energy efficient passive cooling, solar control, photovoltaic, lighting and day lighting, and integrated energy systems. It is well known that thermal mass with night ventilation can reduce the maximum indoor temperature in buildings in summer. ${ }^{8}$ 
Hence, comfort temperatures may be achieved by proper application of passive cooling systems. However, energy can also be saved if an air conditioning unit is used. ${ }^{9}$ The reason for this is that in summer, heavy external walls delay the heat transfer from the outside into the inside spaces. Moreover, if the building has a lot of internal mass the increase in the air temperature is slow. This is because the penetrating heat raises the air temperature as well as the temperature of the heavy thermal mass. The result is a slow heating of the building in summer as the maximal inside temperature is reached only during the late hours when the outside air temperature is already low. The heat flowing from the inside heavy walls can be removed with good ventilation in the evening and night. The capacity to store energy also helps in winter, since energy can be stored in walls from one sunny winter day to the next cloudy one.

\section{Energy use in agriculture}

The land area required to provide all our energy is a small fraction of the land area required to produce our food, and the land best suited for collecting solar energy (rooftops and deserts) is the land least suited for other purposes. The economical utilisation of solar energy in all its varied forms- photovoltaic, direct solar thermal, renewable fuels, ocean-thermal, and wind can offer the world the technology, then can conserve valuable non-renewable fossil resources for future generations to enjoy, and all can live in a world of abundant energy without pollution. Energy in agriculture is important in terms of crop production and agro-processing for value adding. Human, animal and mechanical energy is extensively used for crop production in agriculture. Energy requirements in agriculture are divided into two groups being direct and indirect.

Direct energy is required to perform various tasks related to crop production processes such as land preparation, irrigation, intercultural, threshing, and harvesting and transportation of agricultural inputs and farm produce. It is seen that direct energy is directly used at farms and on fields. Indirect energy, on the other hand, consists of the energy used in the manufacture, packing and transport of fertilisers, pesticides and farm machinery. As the name implies, indirect energy is not directly used on the farm. Major items for indirect energy are fertilisers, seeds, machinery production and pesticides (Table 1). Calculating energy inputs in agricultural production is more difficult in comparison to the industry sector due to the high number of factors affecting agricultural production. However, considerable studies have been conducted in different countries on energy use in agriculture. ${ }^{10-15}$ Energy use in the agricultural sector depends on the size of the population engaged in agriculture, the amount of arable land and the level of mechanisation. To calculate the energy used in agricultural production or repair of machinery, the following formula is used:

$$
M E=\left(T x C_{a}\right)
$$

Where:

$\mathrm{ME}$ is the machine energy $(\mathrm{MJ} / \mathrm{ha})$

$\mathrm{G}$ is the weight of tractor $(\mathrm{kg})$

$\mathrm{E}$ is the constant that is taken $158.3 \mathrm{MJ} / \mathrm{kg}$ for tractor

$\mathrm{T}$ is the economic life of tractor (h)

$\mathrm{C}_{\mathrm{a}}$ is the effective field capacity $(\mathrm{ha} / \mathrm{h})$

For calculation of $\mathrm{C}_{\mathrm{a}}$, the following equation is used:

$$
C_{a}=\left(\mathrm{S} \times \mathrm{W} \times \mathrm{E}_{f}\right) / 10
$$

Where:

$\mathrm{C}_{\mathrm{a}}$ is the effective field capacity (ha/h)

$\mathrm{W}$ is the working width (m)

$\mathrm{S}$ is the working speed $(\mathrm{km} / \mathrm{h})$

$\mathrm{E}_{\mathrm{f}}$ is the field efficiency (\%)

Agricultural greenhouses have a very poor efficiency of thermal conversion of the received solar energy. This is particularly evident in Europe, where, in a cycle of $24 \mathrm{~h}$, and in winter period, the following constraints are observed:

I. During the day to maintain through ventilation, an inside temperature at a level lower than the excessive temperatures, harmful for the growth and the development of the cultures.

II. At night to assure, by a supply of heating energy, an optional temperature higher than the crucial level of the culture.

Table I Energy equivalent of inputs and outputs

\begin{tabular}{lll}
\hline Input & Unit & Equivalent energy (MJ) \\
\hline Human labour & $\mathrm{h}$ & 2.3 \\
Animal labour & & \\
Horse & $\mathrm{h}$ & 10.1 \\
Mule & $\mathrm{h}$ & 4.04 \\
Donkey & $\mathrm{h}$ & 4.04 \\
Cattle & $\mathrm{h}$ & 5.05 \\
Water buffalo & $\mathrm{h}$ & 7.58 \\
Electricity & $\mathrm{kWh}$ & 11.93 \\
Diesel & $\mathrm{Litre}$ & 56.31 \\
Chemicals fertilisers & & \\
Nitrogen & $\mathrm{kg}$ & 64.4 \\
P2O5 & $\mathrm{kg}$ & 11.96 \\
K2O & $\mathrm{kg}$ & 6.7 \\
Seed & & \\
Cereals and pulses & $\mathrm{kg}$ & 25 \\
Oil seed & $\mathrm{kg}$ & 3.6 \\
Tuber & $\mathrm{kg}$ & 14.7 \\
Output major products & & \\
Cereal and pulses & $\mathrm{kg}$ & 14.7 \\
Sugar beet & $\mathrm{kg}$ & 5.04 \\
Tobacco & $\mathrm{kg}$ & 0.8 \\
Cotton & 11.8 \\
Oil seed & 25 \\
Fruits & & \\
Vegetables & & \\
\hline & & \\
& &
\end{tabular}


Table Continued.....

\begin{tabular}{lll}
\hline Input & Unit & Equivalent energy (MJ) \\
\hline Water melon & $\mathrm{kg}$ & $\mathrm{I} .9$ \\
Onion & $\mathrm{kg}$ & $\mathrm{I} .6$ \\
Potatoes & $\mathrm{kg}$ & 3.6 \\
Olive & $\mathrm{kg}$ & $\mathrm{I} 1.8$ \\
Tea & $\mathrm{kg}$ & 0.8 \\
By-products & & \\
Husk & $\mathrm{kg}$ & 13.8 \\
Straw & $\mathrm{kg}$ & 12.5 \\
Cob & $\mathrm{kg}$ & 18 \\
Seed cotton & $\mathrm{kg}$ & 25 \\
\hline
\end{tabular}

This low thermal efficiency is due to the fact that, in a classic greenhouse, the only usable thermal support is the greenhouse soil, which has a weak thermal inertia. Storage of most of the daily excess energy, in order to reuse it during the night where the temperature is low, is therefore impossible. Among other climatic factors contributing in the development of greenhouse cultivation, the inside air temperature, in contact with the aerial part of the plant, constitutes a dominant representative factor. The impact of heating on the increase of the inside air temperature is very important, because a significant increase of agronomic efficiency in the experimental greenhouse. Explanations for the use of inefficient agricultural-environmental polices include: the high cost of information required to measure benefits on a site-specific basis, information asymmetries between government agencies and farm decision makers that result in high implementation costs, distribution effects and political considerations [16]. Achieving the aim of agric-environment schemes through:
a. Sustain the beauty and diversity of the landscape.
b. Improve and extend wildlife habitats.
c. Conserve archaeological sites and historic features.
d. Improve opportunities for countryside enjoyment.
e. Restore neglected land or features, and
f. Create new habitats and landscapes.

\section{Renewable energy technologies}

Sustainable energy is energy that, in its production or consumption, has minimal negative impacts on human health and the healthy functioning of vital ecological systems, including the global environment. It is an accepted fact that renewable energy is a sustainable form of energy, which has attracted more attention during recent years. A great amount of renewable energy potential, environmental interest, as well as economic consideration of fossil fuel consumption and high emphasis of sustainable development for the future will be needed. Nearly a fifth of all global power is generated by renewable energy sources, according to a new book published by the OECD/IEA. ${ }^{17}$ Renewables for power generation: status and prospects claims that renewables are the second largest power source after coal $(39 \%)$ and ahead of nuclear $(17 \%)$, natural gas (17\%) and oil (8\%). From 1973-2000 renewables grew at 9.3\% a year, and the authors predict this will increase $10.4 \%$ a year to 2010 . Wind power grew fastest at $52 \%$ and will multiply by seven times to 2010, overtaking biopower. Reducing GHGs by production of environmental technology (wind, solar, fuel cells, etc.). The challenge is to match leadership in GHG reduction and production of renewable energy with developing a major research and manufacturing capacity in environmental technologies. More than $50 \%$ of world's area is classified as arid, representing the rural and desert part, which lack electricity and water networks. The inhabitants of such areas obtain water from borehole wells by means of water pumps, which are driven by diesel engines. The diesel motors are associated with maintenance problems, high running cost, and environmental pollution. Alternative methods are pumping by photovoltaic (PV) or wind systems. Renewable sources of energy are regional and site specific. It has to be integrated in the regional development plans.

\section{Solar energy}

The availability of data on solar radiation is a critical problem. Even in developed countries, very few weather stations have been recording detailed solar radiation data for a period of time long enough to have statistical significance. Solar radiation arriving on earth is the most fundamental renewable energy source in nature. It powers the bio-system, the ocean and atmospheric current system and affects the global climate. Reliable radiation information is needed to provide input data in modeling solar energy devices and a good database is required in the work of energy planners, engineers, and agricultural scientists. In general, it is not easy to design solar energy conversion systems when they have to be installed in remote locations. Firstly, in most cases, solar radiation measurements are not available for these sites. Secondly, the radiation nature of solar radiation makes difficult the computation of the size of such systems.

While solar energy data are recognised as very important, their acquisition is by no means straightforward. The measurement of solar radiation requires the use of costly equipment such as pyrheliometers and pyranometers. Consequently, adequate facilities are often not available in developing countries to mount viable monitoring programmes. This is partly due to the equipment cost and also the cost of technical manpower. Several attempts have, however, been made to estimate solar radiation through the use of meteorological and other physical parameter in order to avoid the use of expensive network of measuring instruments. ${ }^{18-21}$ Two of the most essential natural resources for all life on the earth and for man's survival are sunlight and water. Sunlight is the driving force behind many of the RETs. The worldwide potential for utilizing this resource, both directly by means of the solar technologies and indirectly by means of bio fuels, wind and hydro technologies are vast. During the last decade interest has been refocused on renewable energy sources due to the increasing prices and fore-seeable exhaustion of presently used commercial energy sources.

The most promising solar energy technology are related to thermal systems; industrial solar water heaters, solar cookers, solar dryers for peanut crops, solar stills, solar driven cold stores to store fruits and vegetables, solar collectors, solar water desalination, solar ovens, and solar commercial bakers. Solar PV system: solar PV for lighting, solar refrigeration to store vaccines for human and animal use, solar PV for water pumping, solar PV for battery chargers, solar PV for communication network, microwave, receiver stations, radio systems in airports, VHF and beacon radio systems in airports, and educational solar TV posts in villages. Solar pumps are most cost effective for low power requirement (up to $5 \mathrm{~kW}$ ) in remote places. Applications 
include domestic and livestock drinking water supplies, for which the demand is constant throughout the year, and irrigation. The suitability of solar pumping for irrigation is uncertain because the demand may vary greatly with seasons. Solar systems may be able to provide trickle irrigation for fruit farming, but not usually the large volumes of water needed for wheat growing.

The hydraulic energy required to deliver a volume of water is given by the formula:

$$
E_{w}=\rho_{w} V H
$$

Where $E_{w}$ is the required hydraulic energy $\left(\mathrm{kWh}^{\text {day }}{ }^{-1}\right) ; \rho_{\mathrm{w}}$ is the water density; $\mathrm{g}$ is the gravitational acceleration $\left(\mathrm{ms}^{-1}\right)$; $\mathrm{V}$ is the required volume of water $\left(\mathrm{m}^{3} \mathrm{day}^{-1}\right)$; and $\mathrm{H}$ is the head of water $(\mathrm{m})$.

The solar array power required is given by:

$$
\mathrm{P}_{s a}=\mathrm{E}_{w} / \mathrm{E}_{s r} \eta F
$$

Where: $\mathrm{P}_{\mathrm{sa}}$ is the solar array power $\left(\mathrm{kW}_{\mathrm{p}}\right)$; $\mathrm{E}_{\mathrm{sr}}$ is the average daily solar radiation $\left(\mathrm{kWhm}^{-2} \mathrm{day}^{-1}\right) ; \mathrm{F}$ is the array mismatch factor; and $\eta$ is the daily subsystem efficiency.

Substituting Eq. (1) in Eq. (2), the following equation is obtained for the amount of water that can be pumped:

$$
\mathrm{v}=\mathrm{P}_{s a} \eta F / \rho_{w} g H
$$

PV consists of 32 modules $P_{\text {sa }}=1.6 \mathrm{~kW}_{\mathrm{p}}, \mathrm{F}=0.85, \eta=40 \%$.

A further increase of the PV depends on the ability to improve the durability, performance and the local manufacturing capabilities of the PV. Moreover, the availability of credit schemes (e.g., solar funds) would increase the annual savings of oil and foreign currency and further improve the security of energy supply and further employment could be created.

\section{Efficient bio-energy use}

The data required to perform the trade-off analysis simulation can be classified according to the divisions given in Table 2.The overall system or individual plants, and the existing situation or future development.

Table 2 Classifications of data requirements

\begin{tabular}{lll}
\hline & Plant data & System data \\
\hline Size & Peak load \\
Life & Load shape \\
Cost (fixed and var. O\&M) & Capital costs \\
Existing data & Forced outage & Fuel costs \\
& Maintenance & Depreciation \\
& Efficiency & Rate of return \\
& Fuel & Taxes \\
& Emissions & \\
All of above, plus & System lead growth \\
& Capital costs & Fuel price growth \\
& Construction trajectory & Fuel import limits \\
& Date in service & Inflation \\
\hline
\end{tabular}

The effective economic utilizations of these resources are shown in Table 3, but their use is hindered by many problems such as those related to harvesting, collection, and transportation, besides the photosanitary control regulations. Biomass energy is experiencing a surge in interest stemming from a combination of factors, e.g., greater recognition of its current role and future potential contribution as a modern fuel, global environmental benefits, its development and entrepreneurial opportunities, etc. Possible routes of biomass energy development are shown in Table 4.

Table 3 Effective biomass resource utilization

\begin{tabular}{|c|c|c|c|}
\hline Source & Process & Product & End use \\
\hline \multirow{10}{*}{$\begin{array}{l}\text { Agricultural } \\
\text { residues }\end{array}$} & & & Rural poor \\
\hline & Direct & Combustion & Urban household \\
\hline & & & Industrial use \\
\hline & & & Industrial use \\
\hline & Processing & Briquettes & $\begin{array}{l}\text { Limited household } \\
\text { use }\end{array}$ \\
\hline & Processing & $\begin{array}{l}\text { Carbonisation } \\
\text { (small scale) }\end{array}$ & $\begin{array}{l}\text { Rural household } \\
\text { (self sufficiency) }\end{array}$ \\
\hline & - & Briquettes & Urban fuel \\
\hline & Carbonisation & Carbonised & Energy services \\
\hline & - & Biogas & Household \\
\hline & Fermentation & - & Industry \\
\hline \multirow{5}{*}{$\begin{array}{l}\text { Agricultural, } \\
\text { and animal } \\
\text { residues }\end{array}$} & Direct & Combustion & $\begin{array}{l}\text { (Save or less } \\
\text { efficiency as } \\
\text { wood) }\end{array}$ \\
\hline & Briquettes & $\begin{array}{l}\text { Direct } \\
\text { combustion }\end{array}$ & $\begin{array}{l}\text { (Similar end } \\
\text { use devices or } \\
\text { improved) }\end{array}$ \\
\hline & Carbonisation & Carbonised & Use \\
\hline & Carbonisation & Briquettes & Briquettes use \\
\hline & Fermentation & Biogas & Use \\
\hline
\end{tabular}

\begin{tabular}{lll}
\hline Subject & Tools & Constraints \\
\hline $\begin{array}{l}\text { Utilization and } \\
\text { land clearance } \\
\text { for agriculture } \\
\text { expansion }\end{array}$ & Control & Policy \\
& Conversion & Fuel-wood planning \\
& Technology & Lack of extension \\
& Briquetting & Institutional \\
$\begin{array}{l}\text { Utilization of } \\
\text { agricultural } \\
\text { residues }\end{array}$ & Carbonization & - \\
& Carbonization and briquetting & Policy and legislation \\
& Fermentation & Social acceptability \\
& Gasification & -
\end{tabular}

Table 4 Agricultural residues routes for development 


\section{A. Biomass energy for domestic needs}
i. Population increase
ii. Urbanization
iii. Agricultural expansion
iv. Fuel-wood crisis
v. Ecological crisis
vi. Fuel-wood plantations
vii. Community forestry
viii. Improved stoves
ix. Agro-forestry
$\mathrm{x}$. Improved charcoal production
xi. Residue utilization

\section{B. Biomass energy for petroleum substitution}
i. Oil price increase
ii. Balance of payment problems
iii. Economic crisis
iv. Fuel-wood plantations
v. Residue utilization
vi. Wood based heat and electricity
vii. Liquid fuels from biomass
viii. Producer gas technology

\section{Biomass energy for development}
i. Electrification
ii. Irrigation and water supply
iii. Economic and social development
iv. Fuel-wood plantations
v. Community forestry
vi. Agro-forestry
vii. Briquettes
viii. Producer gas technology

The use of biomass through direct combustion has long been, and still is, the most common mode of biomass utilization as shown in Tables (2-4). Examples for dry (thermo-chemical) conversion processes are charcoal making from wood (slow pyrolysis), gasification of forest and agricultural residues (fast pyrolysis-this is still in demonstration phase), and of course, direct combustion in stoves, furnaces, etc. Wet processes require substantial amount of water to be mixed with the biomass. Biomass technologies include: Briquetting, Improved stoves, Biogas, Improved charcoal, Carbonization, and Gasification.

Briquette processes: Charcoal stoves are very familiar to African society. As for the stove technology, the present charcoal stove can be used, and can be improved upon for better efficiency. This energy term will be of particular interest to both urban and rural households and all the income groups due to the simplicity, convenience, and lower air polluting characteristics. However, the market price of the fuel together with that of its end-use technology may not enhance its early high market penetration especially in the urban low income and rural households.

Briquetting is the formation of a char (an energy-dense solid fuel source) from otherwise wasted agricultural and forestry residues. One of the disadvantages of wood fuel is that it is bulky with a low energy density and is therefore enquire to transport. Briquette formation allows for a more energy-dense fuel to be delivered, thus reducing the transportation cost and making the resource more competitive. It also adds some uniformity, which makes the fuel more compatible with systems that are sensitive to the specific fuel input.

Improved cook stoves : Traditional wood stoves can be classified into four types: three stone, metal cylindrical shaped, metal tripod and clay type. Another area in which rural energy availability could be secured where woody fuels have become scarce, are the improvements of traditional cookers and ovens to raise the efficiency of fuel saving. Also, is by planting fast growing trees to provide a constant fuel supply. The rural development is essential and economically important since it will eventually lead to better standards of living, people's settlement, and self sufficient in the following:

a. Food and water supplies.

b. Better services in education and health care.

c. Good communication modes.

Biogas technology: Biogas technology can not only provide fuel, but is also important for comprehensive utilization of biomass forestry, animal husbandry, fishery, agricultural economy, protecting the environment, realizing agricultural recycling, as well as improving the sanitary conditions, in rural areas. The introduction of biogas technology on wide scale has implications for macro planning such as the allocation of government investment and effects on the balance of payments. Factors that determine the rate of acceptance of biogas plants, such as credit facilities and technical backup services, are likely to have to be planned as part of general macro-policy, as do the allocation of research and development funds. ${ }^{22}$

Improved forest and tree management: Dry cell batteries are a practical but expensive form of mobile fuel that is used by rural people when moving around at night and for powering radios and other small appliances. The high cost of dry cell batteries is financially constraining for rural households, but their popularity gives a good indication of how valuable a versatile fuel like electricity is in rural area. Dry cell batteries can constitute an environmental hazard unless they are recycled in a proper fashion (Table 5). Direct burning of fuelwood and crop residues constitute the main usage of biomass, as is the case with many developing countries. However, the direct burning of biomass in an inefficient manner causes economic loss and adversely affects human health. In order to address the problem of inefficiency, research centres around the world have investigated the viability of converting the resource to a more useful form, namely solid briquettes and fuel gas. Biomass resources play a significant role in energy supply in all developing countries. Biomass resources should be divided into residues or dedicated resources, the latter including firewood and charcoal can also be produced from forest residues (Table 6). 
Table 5 Energy carrier and energy services in rural areas

\begin{tabular}{ll}
\hline Energy carrier & Energy end-use \\
\hline Fuel-wood & Cooking \\
& Water heating \\
& Building materials \\
& Animal fodder preparation \\
Kerosene & Lighting \\
& Ignition fires \\
Dry cell batteries & Lighting \\
& Small appliances \\
Animal power & Transport \\
& Land preparation for farming \\
& Food preparation (threshing) \\
& Transport \\
Human power & Land preparation for farming \\
& Food preparation (threshing) \\
\hline
\end{tabular}

Table 6 Biomass residues and current use

\begin{tabular}{|c|c|}
\hline Type of residue & Current use \\
\hline Wood industry waste & Residues available \\
\hline Vegetable crop residues & Animal feed \\
\hline Food processing residue & Energy needs \\
\hline $\begin{array}{l}\text { Sorghum, millet, wheat } \\
\text { residues }\end{array}$ & Fodder, and building materials \\
\hline Groundnut shells & Fodder, brick making, direct fining oil mills \\
\hline Cotton stalks & $\begin{array}{l}\text { Domestic fuel considerable amounts available } \\
\text { for short period }\end{array}$ \\
\hline Sugar, bagasse, molasses & $\begin{array}{l}\text { Fodder, energy need, ethanol production } \\
\text { (surplus available) }\end{array}$ \\
\hline Manure & Fertilizer, brick making, plastering \\
\hline
\end{tabular}

Gasification application: Gasification is based on the formation of a fuel gas (mostly $\mathrm{CO}$ and $\mathrm{H}_{2}$ ) by partially oxidising raw solid fuel at high temperatures in the presence of steam or air. The technology can use wood chips, groundnut shells, sugar cane bagasse, and other similar fuels to generate capacities from $3 \mathrm{~kW}$ to $100 \mathrm{~kW}$. Three types of gasifier designs have been developed to make use of the diversity of fuel inputs and to meet the requirements of the product gas output (degree of cleanliness, composition, heating value, etc.). ${ }^{22}$

\section{Combined heat and power (CHP)}

Denmark has broadly seen three scales of the CHP which where largely implemented in the following chronological order: ${ }^{23}$
a. Large-scale CHP in cities ( $>50 \mathrm{MWe})$
b. Small (5 kWe-5 MWe) and medium-scale (5-50 MWe)
c. Industrial and small-scale CHP

Most of the heat is produced by large CHP plants (Table 7) (gasfired combined cycle plants using natural gas, biomass, waste or biogas) as shown in Table 7. The DH is energy efficient because of the way the heat is produced and the required temperature level is an important factor. Buildings can be heated to temperature of $21^{\circ} \mathrm{C}$ and domestic hot water (DHW) can be supplied with a temperature of $55^{\circ} \mathrm{C}$ using energy sources that are most efficient when producing low temperature levels $\left(<95^{\circ} \mathrm{C}\right)$ for the $\mathrm{DH}$ water. Most of these heat sources are $\mathrm{CO}_{2}$ neutral or emit low levels. Only a few of these sources are available to small individual systems at a reasonably cost, whereas DH schemes because of the plant's size and location can have access to most of the heat sources and at a low cost. Low temperature $\mathrm{DH}$, with return temperatures of around $30-40^{\circ} \mathrm{C}$ can utilise the following heat sources:

a. Efficient use of the CHP by extracting heat at low calorific value $(\mathrm{CV})$.

b. Efficient use of biomass or gas boilers by condensing heat in economisers (Table 8).

c. Efficient utilisation of geothermal energy.

Table 7 Sources of renewable energy

\begin{tabular}{|c|c|c|}
\hline Energy source & Technology & Size \\
\hline & Domestic solar water heaters & Small \\
\hline \multirow[t]{2}{*}{ Solar energy } & $\begin{array}{l}\text { Solar water heating for large } \\
\text { demands }\end{array}$ & Medium-large \\
\hline & $\begin{array}{l}\text { PV roofs: grid connected systems } \\
\text { generating electric energy }\end{array}$ & Medium-large \\
\hline \multirow[t]{2}{*}{ Wind energy } & Wind turbines (grid connected) & Medium-large \\
\hline & Hydro plants in derivation schemes & Medium-small \\
\hline \multirow[t]{2}{*}{ Hydraulic energy } & $\begin{array}{l}\text { Hydro plants in existing water } \\
\text { distribution networks }\end{array}$ & Medium-small \\
\hline & High efficiency wood boilers & Small \\
\hline Biomass & $\begin{array}{l}\text { CHP plants fed by agricultural } \\
\text { wastes or energy crops }\end{array}$ & Medium \\
\hline \multirow[t]{3}{*}{ Animal manure } & CHP plants fed by biogas & Small \\
\hline & High efficiency lighting & Wide \\
\hline & High efficiency electric & Wide \\
\hline \multirow{3}{*}{$\mathrm{CHP}$} & Householders appliances & Wide \\
\hline & High efficiency boilers & Small-medium \\
\hline & $\begin{array}{l}\text { Plants coupled with refrigerating } \\
\text { absorption machines }\end{array}$ & Medium-large \\
\hline
\end{tabular}

\section{Hydrogen production}

Hydrogen is now beginning to be accepted as a useful form for storing energy for reuse on, or for export off, the grid. Clean electrical power harvested from wind and wave power projects can be used to produce hydrogen by electrolysis of water- splitting this into its constituent parts of hydrogen and oxygen. Electrolysers split water molecules into its constituent parts: hydrogen and oxygen. These are collected as gases, hydrogen at the cathode and oxygen at the anode. The process is quite simple. Direct current is applied to the electrodes to initiate the electrolysis process. The reaction that occurs is: 
At the anode:

$4 \mathrm{OH}^{-}=>\mathrm{O}_{2}+2 \mathrm{H}_{2} \mathrm{O}+4 \mathrm{e}^{-}$

At the cathode:
$4 \mathrm{H}_{2} \mathrm{O}+4 \mathrm{é}=>2 \mathrm{H}_{2}+4 \mathrm{OH}^{-}$

The overall reaction is:

$2 \mathrm{H}_{2} \mathrm{O}=>2 \mathrm{H}_{2}+\mathrm{O}_{2}$

Table 8 Final energy projections including biomass (mtoe). ${ }^{24}$

\begin{tabular}{|c|c|c|c|c|}
\hline \multicolumn{5}{|l|}{1995} \\
\hline Region & Biomass & Conventional energy & Total & Share of biomass (\%) \\
\hline Africa & 205 & 136 & 341 & 60 \\
\hline China & 206 & 649 & 855 & 24 \\
\hline East Asia & 106 & 316 & 422 & 25 \\
\hline Latin America & 73 & 342 & 416 & 18 \\
\hline South Asia & 235 & 188 & 423 & 56 \\
\hline Total developing countries & 825 & 1632 & 2456 & 34 \\
\hline Other non-OECD countries & 24 & 1037 & 1061 & 1 \\
\hline Total non-OECD countries & 849 & 2669 & 3518 & 24 \\
\hline OECD countries & 81 & 3044 & 3125 & 3 \\
\hline World & 930 & 5713 & 6643 & 14 \\
\hline \multicolumn{5}{|l|}{2020} \\
\hline Region & Biomass & Conventional energy & Total & Share of biomass (\%) \\
\hline Africa & 371 & 266 & 631 & 59 \\
\hline China & 224 & 1524 & 1748 & 13 \\
\hline East Asia & 118 & 813 & 931 & 13 \\
\hline Latin America & 81 & 706 & 787 & 10 \\
\hline South Asia & 276 & 523 & 799 & 35 \\
\hline Total developing countries & 1071 & 3825 & 4896 & 22 \\
\hline Other non-OECD countries & 26 & 1669 & 1695 & 1 \\
\hline Total non-OECD countries & 1097 & 5494 & 6591 & 17 \\
\hline OECD countries & 96 & 3872 & 3968 & 2 \\
\hline World & 1193 & 9365 & 10558 & 11 \\
\hline
\end{tabular}

Production of hydrogen is an elegant environmental solution. Hydrogen is the most abundant element on the planet, it cannot be destroyed (unlike hydrocarbons) it simply changes state- water to hydrogen and back to water- during consumption. In its production and consumption there is no $\mathrm{CO}$ or $\mathrm{CO}_{2}{ }^{24}$ production and depending upon methods of consumption, the production of oxides of nitrogen can be avoided too. The transition will be very messy, and will take many technological paths- converting fossil fuels and methanol to hydrogen, building hybrid engines and so on- but the future will be hydrogen fuel cells. Hydrogen is already produced in huge volumes and used in a variety of industries. Current worldwide production is around 500billion $\mathrm{Nm}^{3}$ per year. ${ }^{25}$ Most of the hydrogen produced today is consumed on-site, such as at oil refineries, and is not sold on the market. From large-scale production, hydrogen costs around $\$ 0.70$ / $\mathrm{kg}$ if it is consumed on-site. ${ }^{25}$ When hydrogen is sold on the market, the cost of liquefying the hydrogen and transporting it to the user adds considerably to production cost. The energy required to produce hydrogen via electrolysis (assuming $1.23 \mathrm{~V})$ is about $33(\mathrm{kWh} / \mathrm{kg})$.
For 1 mole $(2 \mathrm{~g})$ of hydrogen the energy is about $0.066(\mathrm{kWh} / \mathrm{mole}) .^{25}$ The achieved efficiencies are over $80 \%$ and on this basis electrolytic hydrogen can be regarded as a storable form of electricity.

Hydrogen can be stored in a variety of forms:

a. Cryogenic; this has the highest gravimetric energy density.

b. High-pressure cylinders; pressures of 10.000 psi are quite normal.

c. Metal hydride absorbs hydrogen, providing a very low pressure and extremely safe mechanism, but is heavy and more expensive than cylinders, and

d. Chemical carriers offer an alternative, with anhydrous ammonia offering similar gravimetric and volumetric energy densities to ethanol and methanol.

Hydrogen can be used in internal combustion engines, fuel cells, turbines, cookers gas boilers, road-side emergency lighting, traffic 
lights or signalling where noise and pollution can be a considerable nuisance, but where traffic and pedestrian safety cannot be compromised.

\section{Hydropower generation}

Hydropower has a valuable role as a clean and renewable source of energy in meeting a variety of vital human needs. Water resources management and benefit sharing and among other points (safe drinking water and sanitation, water for food and rural development, water pollution and ecosystem conservation, disaster mitigation and risk management) the recognition of the role of hydropower as one of the renewable and clean energy sources and that its potential should be realised in an environmentally sustainable and socially acceptable manner. Water is a basic requirement for survival: for drinking, for food, energy production and for good health. As water is a commodity, which is finite and cannot be created, and in view of the increasing requirements as the world population grows, there is no alternative but to store water for use when it is needed. The major challenges are to feed the increasing world population, to improve the standards of living in rural areas and to develop and manage land and water in a sustainable way. Hydropower plants are classified by their rated capacity into one of four regimes: micro $(<50 \mathrm{~kW})$, mini $(50-$ $500 \mathrm{~kW})$, small $(500 \mathrm{~kW}-5 \mathrm{MW})$, and large ( $>5 \mathrm{MW})[30]$. The total world installed hydro capacity today is around $730 \mathrm{GW}$, and 1500 GW more will be built during this century, principally in developing countries in Asia, Africa and South America. The present production of hydroelectricity is only about 18 per cent of the technically feasible potential (and 32 per cent of the economically feasible potential); there is no doubt that a large amount of hydropower development lies ahead. ${ }^{26}$ Table 9, which is reproduced from, ${ }^{26}$ classified hydro plants in the world.

Table 9 World hydro potential and development

\begin{tabular}{|c|c|c|c|c|c|c|}
\hline Continent & Africa & Asia & $\begin{array}{l}\text { Australia \& } \\
\text { Oceania }\end{array}$ & Europe & $\begin{array}{l}\text { North \& } \\
\text { Central } \\
\text { America }\end{array}$ & South America \\
\hline Gross theoretical hydropower potential (GWhy-1) & $4 \times 10^{6}$ & $19.4 \times 10^{6}$ & $59.4 \times 10^{6}$ & $3.2 \times 10^{6}$ & $6 \times 10^{6}$ & $6.2 \times 10^{6}$ \\
\hline Technically feasible hydropower potential (GWhy-1) & $1.75 \times 10^{6}$ & $6.8 \times 10^{6}$ & $2 \times 10^{6}$ & $10^{6}$ & $1.66 \times 10^{6}$ & $2.7 \times 10^{6}$ \\
\hline Economically feasible hydropower potential (GWhy-1) & $1.1 \times 10^{5}$ & $3.6 \times 10^{6}$ & $90 \times 10^{4}$ & $79 \times 10^{4}$ & $10^{6}$ & $1.6 \times 10^{6}$ \\
\hline Installed hydro capacity (MW) & $21 \times 10^{3}$ & $24.5 \times 10^{4}$ & $13.3 \times 10^{4}$ & $17.7 \times 10^{4}$ & $15.8 \times 10^{4}$ & $11.4 \times 10^{4}$ \\
\hline Production by hydro plants in 2002 or average (GWhy') & $83.4 \times 10^{3}$ & $80 \times 10^{4}$ & $43 \times 10^{3}$ & $568 \times 10^{3}$ & $694 \times 10^{3}$ & $55 \times 10^{4}$ \\
\hline Hydro capacity under construction (MW) & $>3024$ & $>72.7 \times 10^{3}$ & $>177$ & $>23 \times 10^{2}$ & $58 \times 10^{2}$ & $>17 \times 10^{3}$ \\
\hline Planned hydro capacity (MW) & $77.5 \times 10^{3}$ & $>17.5 \times 10^{4}$ & $>647$ & $>10^{3}$ & $>15 \times 10^{3}$ & $>59 \times 10^{3}$ \\
\hline
\end{tabular}

\section{Wind energy}

The utilisation of energy from renewable sources, such as wind, is becoming increasingly attractive and is being widely used for the substitution of oil-produced energy, and eventually to minimise atmospheric degradation. Most of the world's energy consumption is greatly dependent on fossil fuel, which is exhaustible and is being used extensively due to the continuous escalation in world's population and development. This valuable resource needs to be converted and its alternatives need to be explored. In this perspective, utilisation of renewables, such as wind energy, has gained considerable momentum since the oil crises of the 1970s. Wind energy is non-depleting, sitedependent, non-polluting, and a potential source of the alternative energy option. Wind power could supply $12 \%$ of global electricity demand by 2020, according to a report by European Wind Energy Association and Greenpeace. ${ }^{27}$ Wind energy can and will constitute a significant energy resource; it must be converted at a usable form (Figure 1).

As Figure 1 illustrates, information sharing is a four-stage process and effective collaboration must also provide ways in which the other three stages of the 'renewable' cycle: gather, convert and utilise, can be integrated. Efficiency in the renewable energy sector translates into lower gathering, conversion and utilisation (electricity) costs. A great level of installed capacity has already been achieved. Figure 2 clearly shows that the offshore wind sector is developed, and this indicates that wind is becoming a major factor in electricity supply with a range of significant technical, commercial and financial hurdles to be overcome. The offshore wind industry has the potential for a very bright future and to emerge as a new industrial sector (Figure 3).

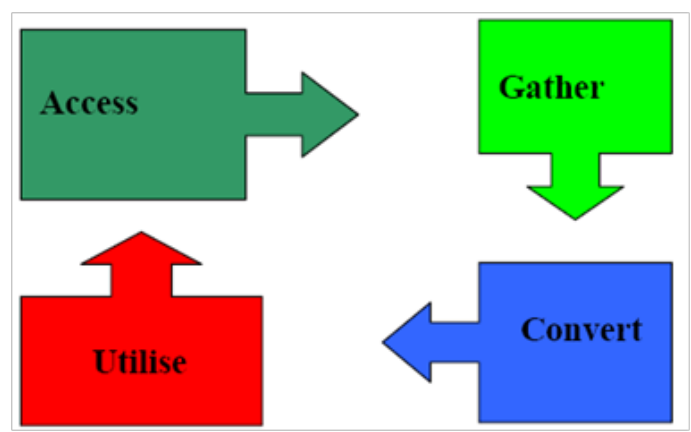

Figure I The renewable cycle.

The speed of turbine development means that more powerful models have superseded the original specification turbines in the time from concept to turbine order. Levels of activities are growing (Figure 4), at phenomenal rate, new prospects are developing, new players are entering and existing players are growing in experience, technology is evolving and political will appears to support the sector. Water is the most natural commodity for the existence of life in the remote desert areas. As a condition of settling and growing, the supply of energy comes into a second priority. The high cost and the difficulties of a main power lines extension, especially to low populated regions can divert the attention to the utilisation of more reliable and independent sources of energy like the renewable wind energy. 


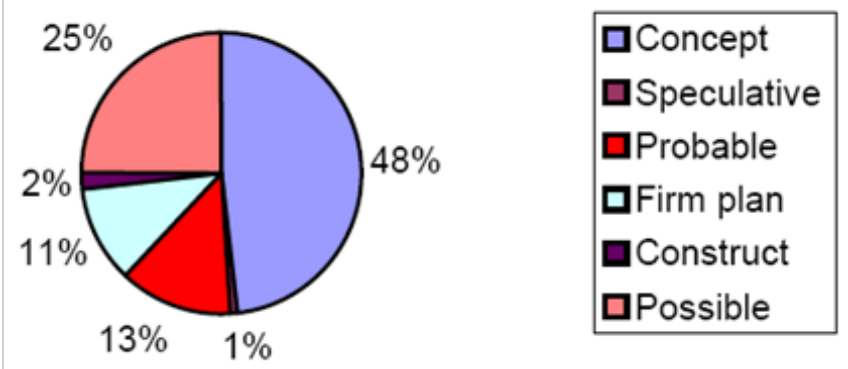

Figure 2 Global prospects by 2003-2010.

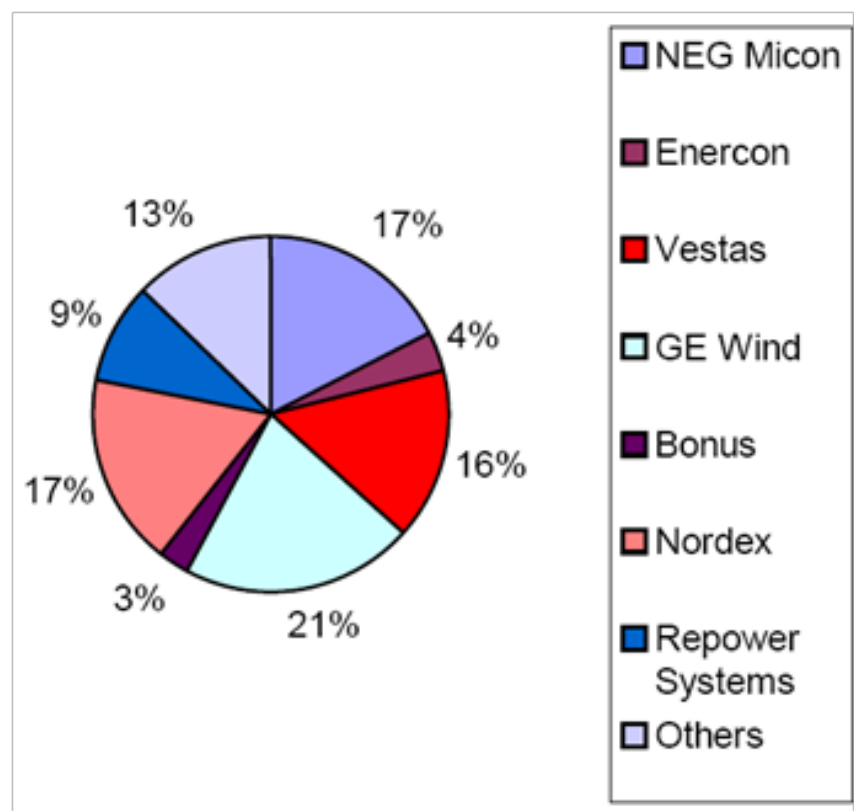

Figure 3 Turbines share for 2003-2010.

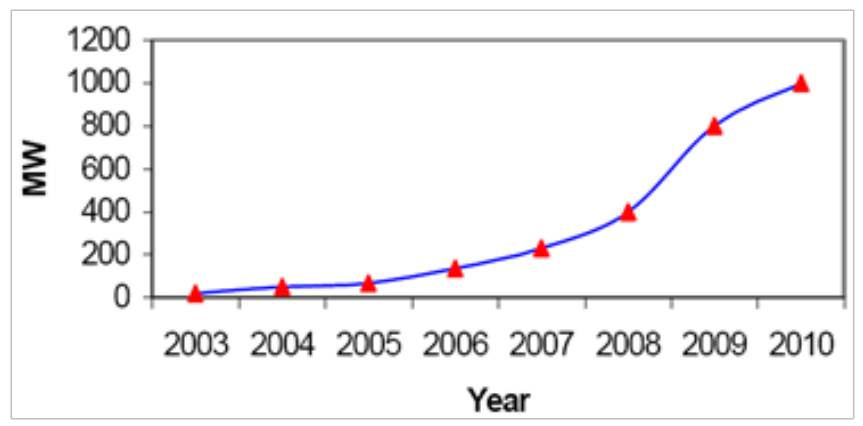

Figure 4 Average windfarm capacity 2003-20I0.

\section{Energy and sustainable development}

Sustainability has been defined as the extent to which progress and development should meet the need of the present without compromising the ability of the future generations to meet their own needs. ${ }^{28}$ This encompasses a variety of levels and scales ranging from economic development and agriculture, to the management of human settlements and building practices. This general definition was further developed to include sustainable building practices and management of human settlements. The following issues were addressed during the Rio Earth Summit in 1992;29
I. The use of local materials and indigenous building sources.

II. Incentive to promote the continuation of traditional techniques, with regional resources and self-help strategies.

III. Regulation of energy-efficient design principles.

IV. International information exchange on all aspects of construction related to the environment, among architects and contractors, particularly non-conventional resources.

V. Exploration of methods to encourage and facilitate the recycling and reuse of building materials, especially those requiring intensive energy use during manufacturing, and the use of clean technologies.

\section{Action areas for producers}

Management and measurement tools- adopting environmental management systems appropriate for the business.

a. Performance assessment tools- making use of benchmarking to identify scope for impact reduction and greater eco-efficiency in all aspects of the business.

b. Best practice tools- making use of free help and advice from government best practice programmes (energy efficiency, environmental technology, and resource savings) (Table 10) (Table 11).

c. Innovation and ecodesign-rethinking the delivery of "value added' by the business, so that impact reduction and resource efficiency are firmly built in at the design stage.

d. Cleaner, leaner production processes- pursuing improvements and savings in waste minimisation, energy and water consumption, transport and distribution, as well as reduced emissions. Tables (10-12) indicate energy conservation, sustainable development and environment.

e. Supply chain management- specifying more demanding standards of sustainability from 'upstream' suppliers, while supporting smaller firms to meet those higher standards.

f. Product stewardship- taking the broadest view of 'producer responsibility' and working to reduce all the 'downstream' effects of products after they have been sold on to customers.

g. Openness and transparency- publicly reporting on environmental performance against meaningful targets; actively using clear labels and declarations so that customers are fully informed; building stakeholder confidence by communicating sustainability aims to the workforce, the shareholders and the local community (Figure 5).

This is the step in a long journey to encourage a progressive economy, which continues to provide us with high living standards, but at the same time helps reduce pollution, waste mountains, other environmental degradation, and environmental rationale for future policy-making and intervention to improve market mechanisms.

This vision will be accomplished by:

A. 'Decoupling' economic growth and environmental degradation. The basket of indicators illustrated shows the progress being made (Table 12) (Table 13). Decoupling air and water pollution from growth, making good headway with $\mathrm{CO}_{2}$ emissions from 
energy, and transport. The environmental impact of our own individual behaviour is more closely linked to consumption expenditure than the economy as a whole.

B. Focusing policy on the most important environmental impacts associated with the use of particular resources, rather than on the total level of all resource use.

C. Increasing the productivity of material and energy use that are economically efficient by encouraging patterns of supply and demand, which are more efficient in the use of natural resources? The aim is to promote innovation and competitiveness. Investment in areas like energy efficiency, water efficiency and waste minimisation.

D. Encouraging and enabling active and informed individual and corporate consumers.

Table 10 Energy and sustainable environment

\begin{tabular}{|c|c|c|}
\hline Technological criteria & $\begin{array}{l}\text { Energy and } \\
\text { environment criteria }\end{array}$ & $\begin{array}{l}\text { Social and } \\
\text { economic criteria }\end{array}$ \\
\hline Primary energy saving in regional scale & $\begin{array}{l}\text { Sustainability according to greenhouse gas } \\
\text { pollutant emissions }\end{array}$ & Labour impact \\
\hline Technical maturity, reliability & $\begin{array}{l}\text { Sustainable according to other pollutant } \\
\text { emissions }\end{array}$ & Market maturity \\
\hline $\begin{array}{l}\text { Consistence of installation and maintenance } \\
\text { requirements with local technical known-how }\end{array}$ & Land requirement & $\begin{array}{l}\text { Compatibility with political, legislative and } \\
\text { administrative situation }\end{array}$ \\
\hline Continuity and predictability of performance & $\begin{array}{l}\text { Sustainability according to other environmental } \\
\text { impacts }\end{array}$ & Cost of saved primary energy \\
\hline
\end{tabular}

Table I I Classification of key variables defining facility sustainability

\begin{tabular}{lll}
\hline Criteria & Intra-system impacts & Extra-system impacts \\
\hline \multirow{2}{*}{ Stakeholder satisfaction } & Standard expectations met & Covered by attending to extra-system resource base and ecosystem impacts \\
& Relative importance of standard expectations & - \\
& Change in intra-system resource bases & Resource flow into/out of facility system \\
Resource base impacts & Significance of change & Unit impact exerted by flow on source/sink system \\
& & Significance of unit impact \\
Ecosystem impacts & Change in intra-system ecosystems & Resource flows into/out of facility system \\
& Significance of change & Unit impact exerted by how on source/sink system \\
\hline
\end{tabular}

Table 12 Positive impact of durability, adaptability and energy conservation on economic, social and environment systems

\begin{tabular}{lll}
\hline Economic system & Social system & Environmental system \\
\hline Durability & Preservation of cultural values & Preservation of resources \\
$\begin{array}{l}\text { Meeting changing needs of } \\
\text { economic development }\end{array}$ & $\begin{array}{l}\text { Meeting changing needs of individuals } \\
\text { and society }\end{array}$ & $\begin{array}{l}\text { Reuse, recycling and preservation of resources } \\
\text { Energy conservation and saving }\end{array}$ \\
$\begin{array}{l}\text { Savings directed to meet other social } \\
\text { needs }\end{array}$ & $\begin{array}{l}\text { Preservation of resources, reduction of pollution and } \\
\text { global warming }\end{array}$ \\
\hline
\end{tabular}

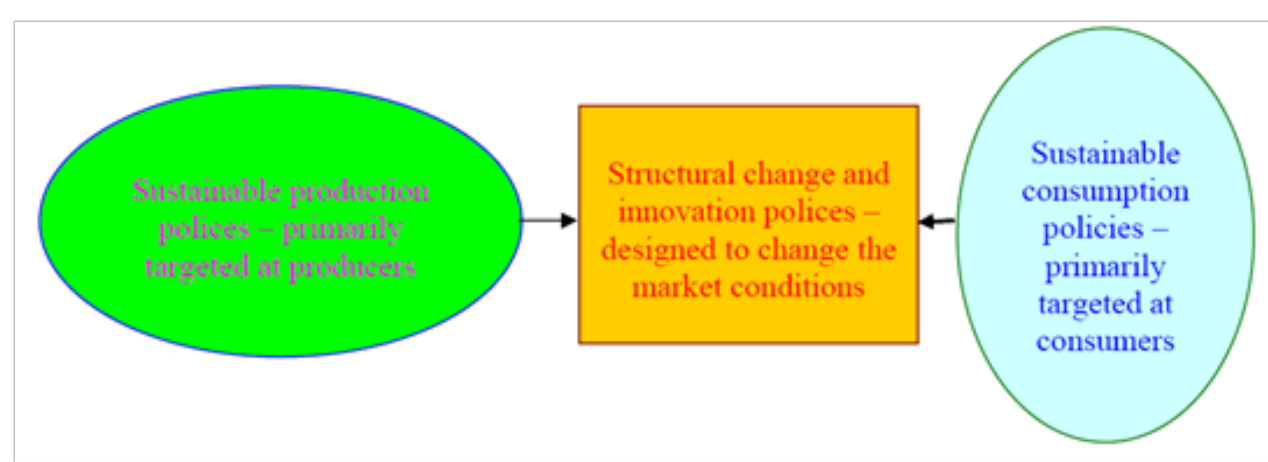

Figure 5 Link between resources and productivity. 
Table I 3 The basket of indicators for sustainable consumption and production

Economy-wide decoupling indicators
Greenhouse gas emissions
Air pollution
Water pollution (river water quality)
Commercial and industrial waste arisings and household waste not
cycled

\section{Resource use indicators}

Material use

Water abstraction

\section{Decoupling indicators for specific sectors}

Emissions from electricity generation

Motor vehicle kilometres and related emissions

Agricultural output, fertiliser use, methane emissions and farmland bird populations

Manufacturing output, energy consumption and related emissions

Household consumption, expenditure energy, water consumption and waste generated

\section{Global warming}

With the debate on climate change, the preference for real measured data has been changed. The analyses of climate scenarios need an hourly weather data series that allows for realistic changes in various weather parameters. By adapting parameters in a proper way, data series can be generated for the site. Weather generators should be useful for:

a. Calculation of energy consumption (no extreme conditions are required)

b. Design purposes (extremes are essential), and

c. Predicting the effect of climate change such as increasing annually average of temperature.

d. This results in the following requirements:

e. Relevant climate variables should be generated (solar radiation: global, diffuse, direct solar direction, temperature, humidity, wind speed and direction) according to the statistics of the real climate.

f. The average behaviour should be in accordance with the real climate.

g. Extremes should occur in the generated series in the way it will happen in a real warm period. This means that the generated series should be long enough to assure these extremes, and series based on average values from nearby stations.

On some climate change issues (such as global warming), there is no disagreement among the scientists. The greenhouse effect is unquestionably real-it is essential for life on earth. Water vapour is the most important GHG; next is carbon dioxide $\left(\mathrm{CO}_{2}\right)$. Without a natural greenhouse effect, scientists estimate that the earth's average temperature would be $18^{\circ} \mathrm{C}$ instead of its present $14^{\circ} \mathrm{C}$. There is also no scientific debate over the fact that human activity has increased the concentration of GHGs in the atmosphere (especially $\mathrm{CO}_{2}$ from combustion of coal, oil and gas). The greenhouse effect is also being amplified by increased concentrations of other gases, such as methane, nitrous oxide, and CFCs as a result of human emissions. Most scientists predict that rising global temperatures will raise the sea level and increase the frequency of intense rain or snowstorms. Climate change scenarios sources of uncertainty and factors influencing the future climate are:

a. The future emission rates of the GHGs (Table 14).

b. The effect of these emissions on the GHGs concentrations in the atmosphere.

c. The effect of this increase in concentration on the energy balance of the atmosphere, and

d. The effect of this change in energy balance on global and regional climate.

Table I4 EU member states greenhouse gas (GHG) emissions

\begin{tabular}{lllll}
\hline Country & 1990 & 1999 & $\begin{array}{l}\text { Change } \\
1990-99\end{array}$ & $\begin{array}{l}\text { Reduction } \\
\text { target }\end{array}$ \\
\hline Austria & 76.9 & 79.2 & $2.60 \%$ & $-13 \%$ \\
Belgium & 136.7 & 140.4 & $2.80 \%$ & $-7.50 \%$ \\
Denmark & 70 & 73 & $4.00 \%$ & $-21.00 \%$ \\
Finland & 77.1 & 76.2 & $-1.10 \%$ & $0.00 \%$ \\
France & 545.7 & 544.5 & $-0.20 \%$ & $0.00 \%$ \\
Germany & 1206.5 & 982.4 & $-18.70 \%$ & $-21.00 \%$ \\
Greece & 105.3 & 123.2 & $16.90 \%$ & $25.00 \%$ \\
Ireland & 53.5 & 65.3 & $22.10 \%$ & $13.00 \%$ \\
Italy & 518.3 & 541.1 & $4.40 \%$ & $-6.50 \%$ \\
Luxembourg & 10.8 & 6.1 & $-43.30 \%$ & $-28.00 \%$ \\
Netherlands & 215.8 & 230.1 & $6.10 \%$ & $-6.00 \%$ \\
Portugal & 64.6 & 79.3 & $22.40 \%$ & $27.00 \%$ \\
Spain & 305.8 & 380.2 & $23.20 \%$ & $15.00 \%$ \\
Sweden & 69.5 & 70.7 & $1.50 \%$ & $4.00 \%$ \\
United Kingdom & 741.9 & 637.9 & $-14.40 \%$ & $-12.50 \%$ \\
Total EU-15 & 4199 & 4030 & $-4.00 \%$ & $-8.00 \%$ \\
\hline
\end{tabular}

It has been known for a long time that urban centres have mean temperatures higher than their less developed surroundings. The urban heat increases the average and peak air temperatures, which in turn affect the demand for heating and cooling. Higher temperatures can be beneficial in the heating season, lowering fuel use, but they exacerbate the energy demand for cooling in the summer times. In temperate climates neither heating nor cooling may dominate the fuel use in a building, and the balance of the effect of the heat is less. As the provision of cooling is expensive with higher environmental cost, ways of using innovative alternative systems like mop fan will be appreciated. The solar gains would effect energy consumption. Therefore, lower or higher percentage of glazing, or incorporating of shading devices might affect the balance between annual heating and cooling load. In addition to conditioning energy, the fan energy needed to provide mechanical ventilation can make a significant further 
contribution to energy demand. Much depends on the efficiency of design, both in relation to the performance of fans themselves and to the resistance to flow arising from the associated ductwork. Figure 6 illustrates the typical fan and thermal conditioning needs for a variety of ventilation rates and climate conditions (Figure 6).

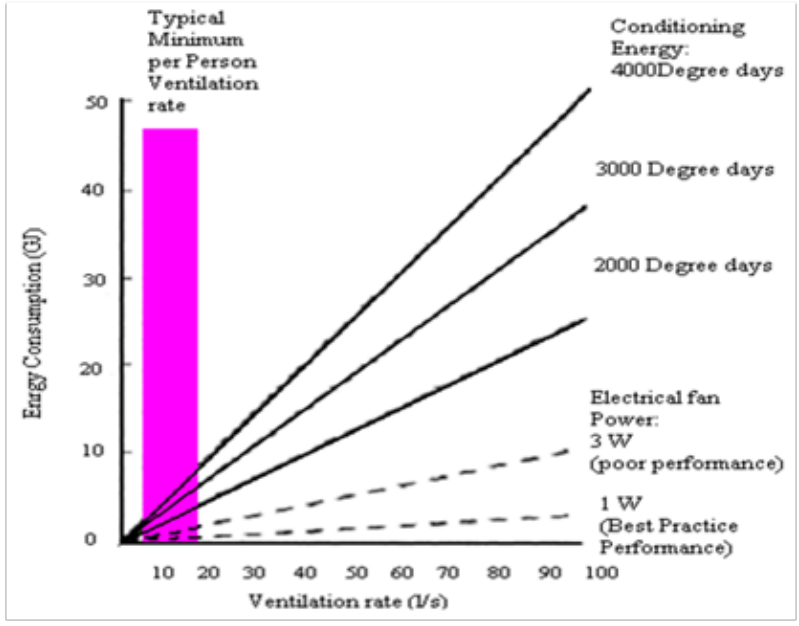

Figure 6 Energy impact of ventilation.

\section{Recommandations}

Launching of public awareness campaigns among local investors particularly small-scale entrepreneurs and end users of RET to highlight the importance and benefits of renewable, particularly solar, wind, and biomass energies. Amendment of the encouragement of investment act, to include furthers concessions, facilities, tax holidays, and preferential treatment to attract national and foreign capital investment. Allocation of a specific percentage of soft loans and grants obtained by governments to augment budgets of R\&D related to manufacturing and commercialisation of RET. Governments should give incentives to encourage the household sector to use renewable energy instead of conventional energy. Execute joint investments between the private sector and the financing entities to disseminate the renewable with technical support from the research and development entities. Availing of training opportunities to personnel at different levels in donor countries and other developing countries to make use of their wide experience in application and commercialisation of RET particularly renewable energy. The governments should play a leading role in adopting renewable energy devices in public institutions e.g., schools, hospitals, government departments, police stations etc. for lighting, water pumping, water heating, communication and refrigeration. To encourage the private sector to assemble, install, repair and manufacture renewable energy devices via investment encouragement, more flexible licensing procedures.

\section{Conclusion}

There is strong scientific evidence that the average temperature of the earth's surface is rising. This was a result of the increased concentration of carbon dioxide and other GHGs in the atmosphere as released by burning fossil fuels. This global warming will eventually lead to substantial changes in the world's climate, which will, in turn, have a major impact on human life and the built environment. Therefore, effort has to be made to reduce fossil energy use and to promote green energies, particularly in the building sector. Energy use reductions can be achieved by minimising the energy demand, by rational energy use, by recovering heat and the use of more green energies. The study was a step towards achieving this goal. The adoption of green or sustainable approaches to the way in which society is run is seen as an important strategy in finding a solution to the energy problem. The key factors to reducing and controlling $\mathrm{CO}_{2}$, which is the major contributor to global warming, are the use of alternative approaches to energy generation and the exploration of how these alternatives are used today and may be used in the future as green energy sources. Even with modest assumptions about the availability of land, comprehensive fuel-wood farming programmes offer significant energy, economic and environmental benefits. These benefits would be dispersed in rural areas where they are greatly needed and can serve as linkages for further rural economic development. The nations as a whole would benefit from savings in foreign exchange, improved energy security, and socio-economic improvements. With a nine-fold increase in forest-plantation cover, the nation's resource base would be greatly improved.

\section{Conflict of interest}

The author declares that there is no conflict of interest.

\section{Acknowledgements}

None.

\section{References}

1. World urbanisation project: the 1999 revision. New York: The United Nations Population Division; 1999. p. 1-12.

2. Rees WE. The built environment and the ecosphere: a global perspective. Building Research and information. 1999;27(4):206-220.

3. Bos E, My T, Vu E, et al. World population projection: 1994-1995. Baltimore and London: World Bank by the John Hopkins University Press, USA; 1994.

4. Energy Use in Offices. Energy Consumption Guide 19 (ECG019) Energy efficiency best practice programme. UK Government, UK, p. 1-24.

5. Givoni B. Climate consideration in building and urban design. New York: Van Nostrand Reinhold, USA; 1998. p. 1-5.

6. ASHRAE, Energy efficient design of new building except new low-rise residential buildings. BSRIASHRAE proposed standards 90-2P-1993, alternative GA. American Society of Heating, Refrigerating, and Air Conditioning Engineers Inc, USA.

7. Kammerud R, Ceballos E, Curtis B, et al. Ventilation cooling of residential buildings. ASHRAE Trans: 90 Part 1B;1984.

8. Shaviv E. The influence of the thermal mass on the thermal performance of buildings in summer and winter. In: Steemers TC, Palz W, editors. Science and Technology at the service of architecture. Dordrecht: Kluwer Academic Publishers, 1989. p. 470-472.

9. Singh J. On farm energy use pattern in different cropping systems in Haryana, India. Germany: International Institute of ManagementUniversity of Flensburg, Sustainable Energy Systems and Management, Master of Science. 2000.

10. CAEEDAC A descriptive analysis of energy consumption in agriculture and food sector in Canada. Final Report, Canada, p.1-26.

11. Yaldiz O, Ozturk H, Zeren Y. Energy usage in production of field crops in Turkey. In: 5th International Congress on Mechanisation and Energy Use in Agriculture. Turkey: Kusadasi, Turkey; 1993.

12. Dutt B. Comparative efficiency of energy use in rice production. Energy. 1982;6:25. 
13. Baruah D. Utilisation pattern of human and fuel energy in the plantation. Journal of Agriculture and Soil Science. 1995;8(2):189-192.

14. Thakur C, Mistra B. Energy requirements and energy gaps for production of major crops in India. Agricultural Situation of India. 1993;48:665-689.

15. Wu J, Boggess W. The optimal allocation of conservation funds. Journal Environmental Economic Management. 1999;38(3):302-321.

16. OECD/IEA. Renewables for power generation: status and prospect. UK; 2004.

17. Duffie JA, Beckman WA. Solar Engineering of Thermal Processes. New York: J Wiley and Sons. 1980. p. 1-928.

18. Sivkov SI. To the methods of computing possible radiation in Italy. Trans Main Geophys Obs. 1964. p.160.

19. Sivkov SI. On the computation of the possible and relative duration of sunshine. Trans Main Geophys Obs. 1964. p. 160.

20. Barabaro S, Coppolino S, Leone C, et al. Global solar radiation in Italy. Solar Energy. 1978;20:431-438.

21. Hall $\mathrm{O}$, Scrase J. Will biomass be the environmentally friendly fuel of the future? Biomass and Bioenergy. 1998;15(4-5):357-367.
22. Pernille M. Feature: Danish lessons on district heating. Energy Resource Sustainable Management and Environmental March/April. 2004. p. $16-17$.

23. Dapote SL. IEA biomass energy analysis and projections. In: Proceedings of Biomass Energy Conference: Data, analysis and Trends. Paris: OECD. 1998. p. 23-24

24. David JM. Developing hydrogen and fuel cell products. Energy World. 2002;303:16-17.

25. IHA 2003 World Atlas \& Industry Guide. The International Journal Hydropower \& Dams, United Kingdom.

26. EWEA Wind force 12. Brussels, Belgium.

27. Steele J. Sustainable architecture: principles, paradigms, and case studies. New York, McGraw-Hill, USA; 1997. p. 288.

28. Sitarz D. Agenda 21: The Earth Summit Strategy to save our planet. Boulder, CO: Earth Press, USA; 1992. p. 315

29. John A, James S. The power of place: bringing together geographical and sociological imaginations. Boston Unwin Hyman, USA; 1989. 